Dossiê: Desafios teológicos do Pluralismo Religioso - Artigo original (c) $($ i)

\title{
Pluralismo no cristianismo primitivo em Éfeso: tensões e estratificações
}

\author{
Pluralism in the Early Christianity in Ephesus: \\ tensions and stratifications
}

\author{
José Adriano Filho* \\ Paulo Augusto de S. Nogueira**
}

\begin{abstract}
Resumo
No cristianismo dos primeiros séculos, encontramos uma pluralidade de escolas e correntes, com luzes e sombras e notáveis conflitos. Considerando isso, este artigo oferece algumas reflexões e análises sobre a existência de pluralismo religioso no cristianismo primitivo na cidade de Éfeso, a capital da província romana da Ásia Menor, sede guardiã do culto imperial. Ele destaca as formas de articulação cultural, sua relação com o poder religioso e político imperial e das regiões nos quais se desenvolveram. Focaliza as formas populares do cristianismo primitivo, entendido como representante do estrato intermediário, ou seja, letrado, mas não erudito, porém capaz de expressar práticas e representações de um conjunto maior de pessoas das camadas subalternas da sociedade. As narrativas analisadas nos oferecem um acesso privilegiado a memórias do pluralismo religioso na cidade de Éfeso nos dois primeiros séculos da era cristã.
\end{abstract}

Palavras-chave: pluralismo religioso; cristianismo primitivo; apóstolo Paulo, Éfeso.

\begin{abstract}
There are a plurality of schools and groups, with lights and shadows and notable conflicts in Christianity of the first centuries. Considering that, this paper offers some thoughts and analysis on the existence of religious pluralism in the early Christianity in the city of Ephesus, the capital of the Roman province of Asia Minor, guardian of the imperial cult. The paper highlights the forms of cultural articulation. It highlights forms of cultural articulation, their relationship with the religious power and imperial political and regions in which they developed. It focuses on popular forms of early Christianity, understood as representative of the intermediate strata, that is, literate, but no scholarly strata, but able to express practices and representations of a larger group of people of the lower strata of society. The narratives analyzed give us a privileged access to memories of religious pluralism in the city of Ephesus in the first two centuries of the Christian era.
\end{abstract}

Keywords: religious pluralism; early Christianity; Paul, the apostle; Ephesus.

Artigo recebido em 31 de agosto de 2015 e aprovado em 23 de novembro de 2015.

* Doutor em Teoria e História Literária pela Universidade Estadual de Campinas - UNICAMP (2013). País de origem: Brasil. E mail: j.adriano1@uol.com.br

*** Doutor em Teologia pela Universidade de Heidelberg (Ruprecht-Karls). País de origem: Brasil. E mail: paulo.nogueira@metodista.br 


\section{Introdução}

O estudo da pluralidade de expressões religiosas e de comunidades no cristianismo primitivo apresenta muitas dificuldades ao pesquisador. Elas são reforçadas por duas posturas básicas. Por um lado, ainda prevalece certa ideologia romântica em relação às origens do cristianismo, de que as suas comunidades fossem um grupo coeso e unitário diante das ameaças do império romano e de grupos heréticos. Por outro lado, há uma tendência pessimista na pesquisa que entende que as fontes são por demais fragmentárias para qualquer reconstrução das primeiras comunidades na antiguidade. De fato, os primeiros cristãos nunca representaram uma força social importante nos dois primeiros séculos e os vestígios institucionais do que tenha sido o cristianismo nesse período são escassos. A perspectiva que o interpreta como uma grande ameaça à dominação romana, constituindo um bloco unitário de oposição, desconsidera o fato de que as autoridades romanas eram ignorantes sobre quem eram os cristãos e quais as suas ideias e práticas até os inícios do segundo século, conforme atestado pela correspondência entre Plínio e Trajano (COMBY; LEMONON, 1987, 46-48). Há nesse caso também desconsideração das tensões internas no cristianismo primitivo, que não eram poucas. Quanto à segunda objeção, temos que admitir que as fontes por meio das quais podemos reconstruir as posturas e posicionamentos ideológicos das comunidades cristãs na antiguidade são de fato fragmentárias, no entanto, paradoxalmente, são mais abundantes do que quaisquer fontes que tenhamos sobre qualquer outro grupo religioso não oficial na antiguidade. Provavelmente, temos mais fontes disponíveis sobre o cristianismo primitivo do que, por exemplo, sobre o culto de Isis, de Mitra ou de Cibele e Atis, todos reconhecidos como cultos muito importantes e disseminados no império romano no mesmo período.

Munidos, portanto, de otimismo, mas também de cautela, queremos oferecer neste artigo algumas reflexões e análises não apenas sobre a existência de pluralismo religioso no cristianismo primitivo (na definição do qual adotamos uma 
cronologia ampla, que inclui o movimento cristão até o início do terceiro século), mas também sobre suas formas de articulação cultural, sua relação com o poder religioso e político imperial e as regiões nos quais se desenvolveram. Nossa análise não será teológica, no sentido de oferecer uma reconstrução e reflexão sobre conjuntos plurais de crenças e doutrinas; no entanto, buscamos oferecer elementos para observar a articulação das comunidades cristãs e de suas diferentes expressões em um mesmo espaço urbano. Nosso foco recairá sobre as formas populares do cristianismo primitivo, sendo popular aqui entendido como representante do estrato intermediário, ou seja, letrado, mas não erudito, porém capaz de expressar práticas e representações de um conjunto maior de pessoas das camadas subalternas da sociedade.

Para podermos proceder a uma análise suficientemente detalhada, no espaço compatível com o de um artigo científico, porém apta a explicitar os pontos acima, decidimos por analisar o Cristianismo Primitivo em apenas uma cidade: Éfeso. Não se trata de uma cidade qualquer. Era a capital da província romana da Ásia (Ásia Menor) e sede guardiã do culto imperial (neokoros), recebendo esse título honorífico por duas vezes. Em Éfeso também está situado um dos templos mais importantes do mundo antigo, o Artemísion, dedicado a Ártemis Efésia. O cristianismo, por sua vez, que se iniciou ali nos anos 50 com a missão paulina, tornou-se um dos mais importantes e plurais do mundo antigo. Se há um lugar do qual podemos saber algo sobre comunidades cristãs na antiguidade, em que pesem todas as dificuldades de análise, trata-se de Éfeso. Temos muitos testemunhos de cristianismo efesino. O primeiro é o testemunho paulino, em algumas referências em suas cartas. Também temos uma carta paulina endereçada a essa comunidade: a Carta aos Efésios. Ela parece ser pseudepigráfica, mas ainda assim se constitui um precioso testemunho de ideias religiosas transmitidas sob a autoridade de Paulo e endereçadas a essa comunidade. Há também uma carta de Ignácio de Antioquia escrita a essa comunidade, no início do segundo século. O Apocalipse de João também tem um interessante, ainda que muito peculiar, testemunho de correspondência à comunidade de Éfeso. Nos capítulos 2 e 3 o profeta João recebe 
a ordem de copiar cartas de autoria do próprio Filho do Homem. Ele lhe ordena enviá-las aos anjos das sete igrejas da Ásia Menor. A primeira delas é a igreja de Éfeso, conhecida por ser aquela que abandonou o seu "primeiro amor" $(2,4)$.

Há outro tipo de testemunho sobre o cristianismo em Éfeso, que utiliza um gênero literário diferente. Trata-se das primeiras reconstruções narrativas sobre as origens do cristianismo nessa cidade, escritas em dois conjuntos de textos: um que tem como referência a atividade de Paulo de Tarso, e outro que enfatiza a ação do apóstolo João. O primeiro se encontra nos Atos dos Apóstolos 18 e 19 e nos Atos Apócrifos de Paulo. O segundo grupo de testemunhas narrativas é formado pelo conjunto de textos apócrifos: Atos de João, Atos de João por Prócoro e os Milagres de João. Em todos esses casos, apesar da diferença de cronologia e de teologia entre elas, são narrativas ficcionais que narram as ações desses apóstolos, atualizando nelas os assuntos do presente de seus leitores. Elas misturam elementos da história romanceada, da biografia antiga e, antes de tudo, da novela grega. Neste artigo nós nos ocuparemos apenas dos testemunhos narrativos que se referem à atuação de Paulo em Éfeso, buscando resgatar memórias de grupos, tendências, movimentos e práticas religiosas. Em alguns casos observaremos tendências conflitantes internas ao movimento cristão. Em outros, tensões com movimentos e instituições de diferentes níveis sociais.

Antes de procedermos à leitura de nossos textos, não podemos deixar de mencionar que há estudos importantes e detalhados sobre o assunto. Uma obra de excepcional poder de análise e detalhe é o livro de Paul Trebilco, The Early Christians in Ephesus from Paul to Ignatius. Seu foco é mais reduzido cronologicamente, tendo Ignácio de Antioquia como limite. Sua obra tampouco considera os elementos que nós propomos neste ensaio, como as relações desse cristianismo com a cultura popular, restringindo-se a uma história de doutrinas. Nosso objetivo é mais modesto, mais delimitado, porém explora uma cronologia mais ampla. Outra obra de referência nos estudos para o estudo do cristianismo 
em Éfeso é a obra organizada por Helmut Koester, Ephesos. Metropolis of Asia. An Interdisciplinary Approach to its Archaeology, Religion, and Culture. Trata-se de uma obra interdisciplinar que conta com a participação de experts nos campos da arqueologia, história da religião e exegese bíblica. Nela há um capítulo importante sobre o papel de Éfeso no cristianismo primitivo, de autoria do organizador. Essa obra contribui de forma especial ao tema e à perspectiva que pretendemos oferecer devido ao fato de não isolar o cristianismo em Éfeso de outros grupos e manifestações religiosas e de suas instituições. Ao contrário, ele é estudado em relação a um contexto amplo, que considera igualmente o culto imperial e o culto de Ártemis Efésia.

\section{Devoções religiosas em Éfeso}

Antes de tratarmos da pluralidade das comunidades cristãs em Éfeso e de suas fontes, é importante fazermos referência ao fato de que há uma considerável pluralidade religiosa nessa cidade, na qual o cristianismo e suas variações apenas constituem uma pequena parte. Trata-se de colocar o objeto de análise em perspectiva correta. O culto mais famoso de Éfeso, cujo templo era considerado uma das maravilhas do mundo antigo, é dedicado a Ártemis Efésia. Trata-se de um culto a uma divindade grega, que chegou a Éfeso no período pré-clássico e que no período romano tinha sua identidade confundida com a da própria cidade. Éfeso era a protetora (neokoros) do templo e da imagem da deusa: Ártemis; era incontestavelmente a principal divindade nos três primeiros séculos de dominação romana na cidade. Nela eram promovidos festivais e procissões em honra à deusa, sendo o mais importante deles o artemísia. Outra celebração importante era a comemoração de seu aniversário (OSTER, 1990, p. 1709). Encontramos uma descrição detalhada do cuidado, rigor, cerimonial e dos custos dessa procissão na inscrição de Salutaris (ROGERS, 2014, p. 80-125). Ali também aprendemos sobre como o poder romano soube se aliar a esse culto e relacioná-lo ao culto imperial. A 
procissão era organizada com verba farta, sofisticação, regramento, ligação com as tribos e famílias importantes, e com o imperador e sua esposa. Era uma honra participar dessa procissão, da mesma forma que a quebra do decoro era punida rigorosamente.

Além do culto público de Ártemis havia também os mistérios de Ártemis, nos quais os Curetas celebravam refeições e ofereciam sacrifícios em Ortígia (OSTER, 1990, p. 1711). Como podemos ver, tratava-se de um culto multifacetado e dinâmico, com desenvolvimentos próprios do período imperial. De acordo com Richard E. Oster:

A natureza e a essência do culto de Ártemis era aberta, como são todas as religiões, a mudança e a fluidez. Mesmo se o sacerdote eunuco, conhecido como Megabizus, sugere ritos de fertilidade similares aos da Deusa Mãe da Ásia Menor, é necessário nos lembrarmos que essa parte do culto desapareceu no período do império romano quando aspectos do seu culto foram adaptados 'em conformidade com ideais helenísticos e romanos (OSTER, 1990, p. 1725-1726).

Apesar do pessimismo de um especialista do porte de Oster, permanece válida, no entanto, a pergunta sobre o quanto possa existir de substrato popular e anatólio no culto de Ártemis, ou seja, quanto do culto de Cibele ou da Deusa Mãe foi incorporado à versão efesina desse culto. Essa pergunta se torna ainda mais importante quando nos perguntamos pelo significado das saliências na parte superior da imagem, que são interpretadas pelos pesquisadores como seios da deusa, ou como testículos dos touros a ela oferecidos. E sendo o seu sacerdote principal, o Megabizus, um eunuco, estamos diante de um culto de fertilidade Anatólio? Não se sabe ao certo. Fato é que os romanos lhe davam um caráter mais cívico, aliado ao decoro da religiosidade romana. As fontes disponíveis se calam sobre elementos de fertilidade no culto da deusa. Essas fontes, no entanto, parecem refletir perspectivas determinadas, aliadas a ideais helenísticos e romanos, como é o caso da descrição da procissão da deusa segundo a abertura da novela de Xenofonte de Éfeso. Nela, a protagonista, Antia, representando a 
deusa na procissão, é descrita como a Ártemis caçadora grega, sem qualquer colorido Anatólio (THOMAS, 1995, p.81-98). Não podemos argumentar a partir do silêncio, no entanto, não parece absurdo imaginar que a devoção doméstica à deusa, associada à proteção da cidade e a arquétipos religiosos vinculados à deusa mãe, possa ter elementos de culto de fertilidade, sem que isso exclua seu caráter de deusa protetora da identidade cívica. Os vestígios literários e arquitetônicos tendem a se calar sobre devoções domésticas.

Éfeso, no entanto, não era apenas a cidade de Ártemis e de seu magnificente templo. Nela havia muitos outros cultos aos deuses gregos, como Afrodite, Asclépio, Atena, Deméter, Dionísio, entre outros. Havia também culto a divindades estrangeiras, como no caso do egípcio Serapis. Heróis eram também venerados, como era o caso de Alexandre e Androclus.

Merece também atenção o culto imperial e a existência de templos dedicados a Domiciano e a Trajano, entre outros. A arquitetura imperial promovia o culto de seus governantes com vários monumentos. A relação especial de Éfeso com o culto imperial pode ser destacada por dois fatos: o primeiro é o fato de que, num contexto de concorrência das cidades da Ásia Menor pelo título de guardiã do culto imperial (neokoros), Éfeso tenha recebido esse título ao menos duas vezes (FRIESEN, 1995). O segundo fato é a forma especial como culto da cidade, o de Ártemis, era articulado com o culto imperial, conforme mencionado.

\section{0 cristianismo primitivo em tensão com religiosidades efesinas}

Vimos acima que o cristianismo em Éfeso não era um fenômeno isolado, ou um protagonista solitário contra o politica e ideologicamente dominante culto imperial. Havia diversidade de grupos religiosos, anatólios, gregos e orientais, e mesmo os mais significativos e centrais, como o culto de Ártemis Efésia, podiam ser venerados em diferentes formas: como deusa-mãe Anatólia, como patrona protetora da cidade ou como divindade legitimadora do poder imperial, etc. 
Essas tensões sutis entre os grupos religiosos também podemos observar na primeira fonte cristã narrativa sobre a missão paulina em Éfeso. Trata-se de Atos dos Apóstolos, capítulos 18 e 19. Nessa obra, escrita pelo menos 40 anos após os fatos narrados, encontramos um primeiro esforço de narrativa histórica das origens, a partir de certa perspectiva ideológica e de adaptações de gêneros literários como a novela grega e a história romanceada. Em analogia à novela grega, o texto é tomado por um tom de aventura e é organizado em torno de viagens (PERVO, 1987, p. 12-57). Os Atos têm uma dupla tendência em sua descrição dos primórdios da missão cristã no mundo mediterrâneo: por um lado, eles aplainam diferenças com o poder imperial, mostrando que os conflitos por acaso existentes foram resultado de mal-entendidos; por outro, a narrativa acirra diferenças internas, como na forma como descreve as tensões com grupos taumatúrgicos e com a sinagoga judaica, conforme veremos abaixo. Se no primeiro aspecto perdemos informações sobre as tensões e os conflitos das comunidades com o poder estabelecido, por outro lado, esses textos nos revelam muito sobre as percepções dessas comunidades sobre seus concorrentes religiosos. É importante ressaltarmos o caráter ficcional e ideologicamente determinado dessa fonte. Temos que identificar-lhe as preferências, os destaques e as omissões. Nada disso, no entanto, a desqualifica como precioso material de estudo das origens do cristianismo e de sua configuração plural. Nosso foco na leitura dos Atos 18 e 19 não recai sobre fatos objetivos, mas sobre representações, perspectivas e sensibilidades socioculturais.

Vejamos, a seguir, a quantidade de grupos e práticas religiosas a que o texto faz referência em apenas dois capítulos. Apesar da estratégia do texto ser a de harmonizar os grupos e de fazê-los gravitar em torno do carisma de Paulo, podemos ainda perceber as tensões entre os grupos nas tramas do texto. 


\subsection{Grupos itinerantes cristãos alternativos (apresentados como cristãos incompletos)}

A narrativa se inicia no capítulo 18 , descrevendo a primeira atuação de Paulo em Éfeso, onde esteve de passagem, em uma viagem que fazia de Corinto, na Acaia, para Antioquia, na Síria, em companhia de Priscila e Áquila. Em sua breve estadia em Éfeso, ele "dirigiu a palavra" aos judeus da sinagoga local. Como lhe pediram para prolongar sua estadia, Paulo prometeu voltar em outra ocasião. Ele retomou sua viagem, embarcando para Cesareia, seguindo depois para Antioquia. Paulo, no entanto, sem que o texto dê mais detalhes sobre sua atuação na Síria, retoma o caminho de volta, desta vez por terra, cruzando a Galácia e a Frígia, em direção a Éfeso. Cabe aqui observar que o texto está saturado de referências étnicas e de localizações geográficas. O tema das viagens e deslocamentos é evidenciado. Os companheiros de viagem de Paulo, Priscila e Áquila, são judeus do Ponto (da parte nordeste da Anatólia), mas acabam de chegar da Itália. Paulo, por sua vez, é judeu de Tarso, e seus demais parceiros, Silas e Timóteo, recém-chegados da Macedônia. Para o leitor comum da Bíblia, trata-se de um exagero de informação geográfica e étnica. Parece-nos que essa percepção é correta, pois nem sempre o texto explora suficientemente as informações que fornece, como, por exemplo, a referência à viagem de Paulo a Antioquia em 18,22-23. O texto apenas menciona que ele, chegado de Éfeso, foi a Cesareia ("saudar os irmãos"), desceu a Antioquia, onde "ficou algum tempo", e já retornou para a região da Galácia e para a Frígia (como que tomando o rumo de volta a Éfeso). Ou seja, é muita informação sem resultar em nenhum dado relevante, a não ser que se considere essa como uma informação que se deseja transmitir: o cristianismo nasce como uma rede plural de conexões e de comunidades. O dado é: essa nova religião não é um fenômeno restrito a Galileus e nem mesmo a judeus, ainda que o texto não consiga esconder que o tempo todo se trata de judeus helenizados que estão em ação.

A mobilidade e a versatilidade cultural dos missionários cristãos estão estruturadas na mobilidade e na versatilidade da comunidade judaica da diáspora. 
Ao contrário do que se pensava até muito recentemente na pesquisa, e do que ainda se pensa no senso comum, os judeus da diáspora não ficavam isolados em seu mundo étnico e religioso: eles falavam grego, estavam representados em sinagogas por todo o mediterrâneo, praticavam formas plurais de judaísmo e permitiam várias formas de adesão de gentios à sua religião e etnia (COHEN, 2000, p. 140-174). Esse é um ponto crucial de nosso argumento: o cristianismo herda do judaísmo da diáspora sua versatilidade cultural e sua pluralidade religiosa. De fato, nas primeiras décadas, ele ainda pode ser compreendido como um grupo religioso dentro de um judaísmo sincrético e plural.

Segundo Atos 18,23, durante a viagem de Paulo, chega a Éfeso um judeu de Alexandria, Apolo, repetindo o paradigma de versatilidade e mobilidade da comunidade judaica tão caro ao livro de Atos. Apolo é descrito como versado nas Escrituras, instruído no "caminho do Senhor", que pregava acerca de Jesus com "exatidão", mas só conhecia o batismo de João. Priscila e Áquila, que haviam ficado em Éfeso, encarregaram-se de ensinar-lhe "mais exatamente" o "caminho de Deus" $(18,26)$. Esse, por sua vez, segue para fazer missão junto a judeus em Corinto. Em seguida, Paulo chega a Éfeso e se defronta com outros discípulos que nunca haviam ouvido falar do Espírito Santo, mas que só conheciam o "batismo de João" (19,1-6). Ao serem doutrinados por Paulo no batismo "no nome do Senhor Jesus”, receberam o Espírito Santo e os dons proféticos (19,6). Em poucos versos somos informados por duas vezes acerca de cristãos que conhecem "apenas o batismo de João"; no segundo caso, de discípulos que, tendo recebido o batismo de João, sequer tinham ouvido falar sobre o Espírito Santo. O texto parece refletir certa estranheza diante desses cristãos exóticos, afinal, toda a experiência cristã estaria fundamentada no cumprimento da profecia de Joel, segundo Atos 2. No entanto, parece-nos injusto, historicamente, considerarmos esses cristãos que conhecem "apenas" o batismo de João como cristãos de segunda categoria, afinal, a que batismo Jesus de Nazaré foi submetido, senão o de João Batista? João Batista gozava de muito prestígio entre os primeiros seguidores de Jesus, sendo 
equiparado aos grandes profetas da história de Israel. A tendência do livro de Atos é considerar o batismo no nome de Jesus, seguido do recebimento do Espírito Santo e de seus dons proféticos, como o padrão da experiência religiosa cristã. No entanto, é possível que outros grupos cristãos tenham permanecido fieis ao batismo de arrependimento e de perdão de pecados de João Batista, como sendo o batismo por excelência dos seguidores de Jesus. Não devemos, dessa forma, imaginar que esses cristãos fossem cristãos incompletos. O próprio texto sugere que eles tinham sofisticação exegética e doutrinária, apresentando Apolo como "eloquente" e "versado nas Escrituras".

\subsection{Sinagoga judaica e escolas de estudo da Torá (o paradigma da rejeição clássica do Messias)}

Segundo Atos 19,8, Paulo pregou por três meses na sinagoga judaica, onde encontrou resistência. Isso o levou a passar a se reunir com pessoas para a pregação na "escola de Tirano". Não se sabe o que seria essa instituição; em todo o caso, nela ele seguiu a pregar por dois anos, sendo ouvido por judeus e gentios. O dado básico aqui é que Paulo se utiliza da estrutura sinagogal para a sua pregação missionária. Não há nesse procedimento qualquer desonestidade da parte dele, como se estivesse se infiltrando na sinagoga. A sinagoga era a instituição que organizava a vida de toda a comunidade judaica numa cidade na diáspora. Nela havia liturgia, estudo da Torá, e também reuniões sociais, organização e administração de aspectos práticos da vida da comunidade. Era uma instituição religiosa, administrativa e educacional. Paulo, como judeu, como pregador itinerante de um messias judeu, tinha como referência natural de sua ação a participação na sinagoga. Nela também ele teria encontrado e convertido os primeiros gentios, afinal, havia gentios que, em diferentes graus, associavam-se à comunidade judaica (COHEN, 2000, p. 140-174).

Essa estratégia paulina de chegar numa cidade grega e procurar a sinagoga judaica é apresentada de forma muito insistente no livro de Atos, criando um 
modelo: chegada - visita à sinagoga - pregação sobre o Messias Jesus - rejeição denúncia de Paulo às autoridades por parte da comunidade judaica. Encontramos esse modelo pela primeira vez em Atos 13, por ocasião da pregação de Paulo na sinagoga de Antioquia da Psídia. Ali ele pregou sobre a boa nova do Messias Jesus, dirigindo-se aos "Israelitas e tementes a Deus" $(13,16)$, ou seja, a um público composto de judeus e de gentios associados à sinagoga. Ao final de sua pregação, esse grupo de "judeus e de tementes prosélitos" se deixaram convencer pela mensagem. No entanto, ao voltar Paulo àquela sinagoga no sábado seguinte, tendo ali a cidade reunida para escutá-lo, “os judeus foram tomados de furor”. Paulo lhes responde que, devido à sua rejeição ("vos julgais indignos da vida eterna", v.46), ele se voltaria agora aos gentios. Segundo o texto, a reação dos pagãos é de alegria, mas os judeus, por sua vez, teriam promovido agitação junto a "mulheres de alta posição" e a autoridades da cidade, que frequentavam a sinagoga, para que expulsassem Paulo. Afinal, nenhuma elite local gostaria de estar associada a qualquer grupo de insidiosos. Esse paradigma de pregação e rejeição na comunidade judaica, com o resultado de exposição dos missionários junto às autoridades locais ou romanas, se repete por todo o livro. A pesquisa bíblica se divide na avaliação histórica desse paradigma narrativo de Atos dos Apóstolos: ele reflete um padrão consistente de ação missionária e a natural rejeição por parte da sinagoga, ou seria apenas um enredo literário criado por Lucas para dar um tom de aventura e de heroísmo à narrativa da ação dos missionários? Entendemos que não é absurdo o modelo proposto pelo livro, ainda que ele seja por demais simplificado para corresponder às complexidades das relações históricas em jogo. A sinagoga era sim o local de encontro social e de debates religiosos dos judeus na diáspora. Era ali que os missionários cristãos fariam seus primeiros convertidos urbanos, judeus e gentios. É também compreensível que os líderes das sinagogas se opusessem aos missionários cristãos, afinal, o apelo à conversão a um messias crucificado não era, necessariamente, um discurso dos mais convincentes e sedutores. Após a Guerra Judaica (66-70) e a destruição de Jerusalém, com a implantação do fiscus judaicos por Vespasiano, e as crescentes demonstrações de 
antissemitismo e de suspeitas políticas contra as comunidades judaicas na diáspora, é minimamente compreensível que lideranças sinagogais quisessem distanciar-se publicamente de pregadores de um messias crucificado pelos romanos ou de qualquer outro tipo de messianismo. Essas tensões, de pertença à sinagoga e de afastamento da mesma, marcarão a tônica de toda a ação missionária de Paulo, segundo Atos dos Apóstolos. É essa relação ambígua e tensa que encontramos na memória da missão paulina na sinagoga de Éfeso. Paulo se dirigiu à Sinagoga, tentou convencer seus ouvintes a "pregar com convicção" $(19,8)$. Alguns o rejeitaram e difamaram "o caminho", diante da assembleia (v.9). Paulo, por sua vez, tomou consigo os discípulos e lhes dirigia a palavra na "escola de Tirano". Essa situação se deu por dois anos, reunindo judeus e gregos.

O que viria a ser essa escola de Tirano? Os comentaristas se contentam em dizer que Tirano poderia ser o dono da sala alugada por Paulo (WEISER, 1985, p. 528). Entendemos, no entanto, que pode perfeitamente se tratar de uma escola de estudo da Torá que recepcionou a Paulo. Nunca saberemos ao certo do que se trata a "escola de Tirano", uma vez que ela só é mencionada aqui, em nosso texto. Manteremos a interpretação conjectural de que se trata de uma escola da Torá dos judeus de Éfeso, na qual Paulo era recebido para ensinar. Entendemos que essa resposta se encaixa melhor no quadro plural que descrevemos da sinagoga judaica. As informações que levantaremos a seguir confirmam ainda mais esse perfil.

\subsection{Grupos taumatúrgicos e seus concorrentes (na busca por cooptação do poder do milagreiro mais poderoso)}

A narrativa de Atos busca dar uma imagem multifacetada de Paulo. Dessa forma, ele não era apenas um pregador e mestre eficiente, ele também era um poderoso milagreiro. Segundo o texto, Deus fazia "coisas poderosas" por meio dele, de tal forma que "a tal ponto que recolhiam, para os aplicar sobre os doentes, lenços e panos que haviam estado em contato com sua pele. Então essas pessoas ficavam curadas de suas doenças, e os espíritos maus se retiravam” $(19,12)$. Aqui o texto trabalha num registro distinto do que vimos acima ao enfatizar a ousadia e 
autoridade de Paulo na apresentação do evangelho e depois ensinando na "escola de Tirano". No parágrafo que se segue (19.11-21), o foco recai sobre o seu poder taumatúrgico de transmitir poder aos objetos que toca, e desses aos enfermos e endemoninhados. Nesse universo mágico, o poder do taumaturgo transborda sua própria pessoa, podendo ser transmitido a objetos, outras pessoas, etc. Trata-se de um âmbito de religiosidade popular, comum no mundo mediterrâneo. Nessa cena, entramos num âmbito totalmente diferente de disputa por poder e legitimidade. A justaposição dessas cenas é surpreendente para nossa sensibilidade moderna, afinal, a pregação de Paulo e seu perfil profético parecem ser de outra ordem do Paulo que transmite poder mágico a lenços e aventais. No entanto, isso não parece ser um problema para nosso texto que, a despeito das suspeitas que pode levantar, está mais interessado em fazer Paulo ocupar muitos espaços no campo religioso de Éfeso. E esse, o da magia, nesses termos tão populares, parece ser, estrategicamente, muito importante.

Nosso texto não está preocupado apenas em enfatizar o poder de Paulo, mas em relatar uma situação de concorrência entre taumaturgos. Se, por um lado, o poder de Paulo passa a roupas e pedaços de pano, por outro lado, pessoas não autorizadas, não alinhadas a seu carisma, não têm o direito de evocar e cooptar o seu poder. Entra em cena um grupo muito enigmático, sobre quem apenas podemos fazer suposições: um grupo de exorcistas judeus ambulantes tentou “invocar o nome do Senhor Jesus sobre os que tinham espíritos maus”. Antes de explorarmos outras informações sobre esses estranhos exorcistas judeus ambulantes, devemos esclarecer que o que eles tentaram fazer era absolutamente legítimo no âmbito da religiosidade popular praticada por eles. Seria ilegítimo, se pensarmos em termos de adesão a um culto mistérico ou a uma comunidade cujo ingresso se desse exclusivamente por meio de ritos de iniciação. Mas na magia popular helenística a evocação de divindades, ancestrais, anjos ou até demônios era esperada, principalmente se essas entidades e divindades fossem poderosas ou tivessem poder em seus nomes. Os nomes de divindades nesse âmbito não eram 
apenas formas de designar, porém fórmulas sagradas que tinham poder em si mesmas. Por isso, não é incomum encontrarmos evocações a diferentes entidades nos Papirus Mágicos Gregos (BETZ, 1992). Ou seja, o critério não é o de pertença doutrinária, ou de autorização de uso por pertença comunitária, mas a associação de divindades e de nomes poderosos entre si, em colaboração, para que se atinja um determinado fim. Nosso texto tenta mostrar que o nome poderoso de Jesus, por meio do qual milagres acontecem, só pode ser usado por Paulo, de forma que até os próprios demônios reconhecem que apenas ele tem legitimidade para tal. Essa narrativa enquadra o tema do poder de Paulo numa batalha de magos. Paulo não só evoca o nome de Jesus para obter poder, como também o transmite a objetos inanimados. Já os exorcistas concorrentes, ao ousar invocar o nome de Jesus, são desacreditados pelos demônios e ainda levam uma surra pública deles: "e isso foi notório a todos os habitantes de Éfeso, tanto judeus quanto gregos" (v.17). Maior humilhação impossível.

É necessário comentar a identidade desses exorcistas judeus ambulantes. Trata-se dos "sete filhos de Cevas, judeu, sumo sacerdote". Essa é uma das designações mais estranhas de lideranças religiosas no Novo Testamento. Quem era o sumo sacerdote Cevas? Onde exerceu seu ofício? Que faria um grupo de sete filhos do sumo sacerdote em Éfeso? Que sentido faria sua atuação itinerante na Ásia Menor? A pesquisa não pode fazer mais do que especular sobre a identidade dos sete exorcistas. Transfere-se muito de nossa imaginação religiosa no espelho de suas identidades irrecuperáveis. Em primeiro lugar, temos que admitir que designações religiosas são atribuídas. Que alguém seja reconhecido como um "sumo sacerdote" depende das convenções de sua etnia ou de seu grupo social. Vejamos o título "apóstolo", nome dado aos seguidores do Messias Jesus de Nazaré, quando os enviou em missão na Galileia. Com o tempo, esse título se cristalizou e se tornou um elo de ligação e autoridade com a tradição de Jesus. Paulo, que não era um apóstolo original, uma vez que não foi um dos 12 seguidores de Jesus, teve o título a ele atribuído devido a uma visão enviada a ele por Cristo (Atos 9). E ele era efetivamente reconhecido como um apóstolo pelas comunidades 
que ajudou a fundar. Mesmo entre cristãos comuns havia uma expectativa de que eles se tornassem "reinado e sacerdotes" (Ap. 1) para Deus. Em nossa análise, na busca por pluralidade religiosa dos primeiros cristãos, podemos perfeitamente reconhecer a atribuição desse status religioso dos sete exorcistas, filhos do sumo sacerdote Cevas, como autoatribuição de um grupo religioso. É verdade que sacerdócio não combina muito com exorcismo, mas, no âmbito da religião popular, essas atribuições são feitas com mais liberdade. Observem que eram "sete filhos" do sumo sacerdote. Trata-se de um número redondo, como no caso dos "sete diáconos" de Atos 6? O tom da narrativa é de exaltação do poder milagreiro e da autoridade de Paulo, com a correspondente ridicularização dos concorrentes. O texto, no entanto, mostra que o paradigma de atuação dos dois grupos parece ser o mesmo: o da religião taumatúrgica popular helenista, na qual divindades e nomes de divindades podem e devem ser apropriados pelos agentes religiosos. Temos aqui uma preciosa memória de grupos plurais à margem das religiões oficiais de Éfeso. Mesmo com toda a tentativa de legitimação e diferenciação de Atos, temos que listar para esse efeito os dois grupos no mesmo nível.

\subsection{Enfrentamento com o culto de Ártemis Efésia (na perspectiva do fanatismo popular e da manipulação financeira do templo)}

A partir do v.23, a narrativa muda de tom. Se no parágrafo anterior o enfrentamento era com um grupo marginal de exorcistas judeus, agora Paulo e a comunidade cristã sofrem com ameaças e tensões com o templo de Ártemis. A narrativa apresenta esse enfrentamento por meio de um estratagema: quem denuncia a atuação de Paulo e os supostos prejuízos dela decorrentes é um tal de Demétrio, um ourives que fabricava miniaturas de templos de prata e que com isso obtinha consideráveis lucros (v.24). Ele formula sua acusação: "não somente em Éfeso, mas em quase toda a Ásia, esse Paulo agita uma multidão considerável, persuadindo-a, como diz, que os deuses que saem de nossas mãos não são deuses” 
(v.26). As consequências dessa pregação de Paulo são óbvias e afetam seus negócios e o status do templo e da cidade a ele tão fortemente associada: "Não é somente nossa profissão que corre o risco de ficar desacreditada, mas é também o templo da grande deusa Ártemis que poderia ser menosprezado e ver-se, em breve, despojado da grandeza daquela a quem adoram a Ásia e o mundo inteiro" (v.27).

Podemos observar a forma estrategicamente elaborada de nosso narrador organizar a cena e o argumento: Quem se queixa não é um devoto qualquer, alguém que por qualquer motivo tenha recebido alguma graça da deusa, mas um dos ourives, um profissional que alerta seus companheiros de ofício para os riscos a que a atividade deles é submetida pelos missionários cristãos. Ele também adverte aos riscos que o templo e a cidade correm de perder o seu prestígio. Nesse ponto, o argumento de nosso texto é basicamente judaico e monoteísta: o templo e o culto da deusa não passam de atividade lucrativa daqueles que "fabricam" os deuses. Os cultos pagãos são fruto da manipulação de artesãos e do poder político, dado o prestígio que a cidade tem em função do templo. Segundo o texto, os demais artesãos e a população da cidade, entendendo bem do que falava Demétrio, começaram a gritar "Grande é a Ártemis dos Efésios" (v.28). E quando um dos judeus que se encontrava na multidão, que se reunia no teatro, foi empurrado para frente e quis falar, em reação a multidão, gritou "a uma só voz" por duas horas essa mesma aclamação "Grande é a Ártemis dos Efésios". Podemos nos perguntar: o que esse Alexandre, representante da comunidade judaica de Éfeso, fazia no teatro diante dessa confusão? Essa informação inusitada, acrescida do nome grego desse judeu e de seu desejo de "dar uma explicação" à assembleia, é muito estranha. A presença desses missionários cristãos parece desestabilizar o frágil equilíbrio que existe entre essa comunidade judaica helenizada e a cidade, que tem sua identidade e status tão intimamente ligados ao templo da deusa. Por outro lado, podemos observar que a polêmica contra as estátuas e deuses pagãos, que são obras de homens, é tipicamente judaica, nada tendo de especificamente cristão. 


\subsection{O poder do culto imperial (mencionado apenas sutilmente, como uma ameaça)}

A tensão da narrativa iniciada no v.23 chega ao seu ápice quando a multidão, sentindo-se provocada com a presença do judeu Alexandre no teatro, grita por mais de duas horas a aclamação à deusa. Isso faz com que as autoridades tenham que entrar em ação. O secretário (grammateus) da cidade pede a palavra e acalma a multidão com as seguintes palavras: "Efésios, disse ele, existe acaso alguém que não saiba que a cidade de Éfeso é a cidade santa da grande Ártemis e da sua estátua caída do céu?”. Até aqui seu argumento reforça o senso de identidade dos cidadãos em relação à cidade e ao culto da deusa. Mas seu argumento parece ter surtido efeito devido ao conselho: “... deveis, portanto, voltar à calma e evitar falsas manobras (mais literalmente: nada faças precipitadamente)." (v. 36). Ele tenta minimizar o problema afirmando que não houve sacrilégio ou blasfêmia por parte de Paulo, seus seguidores, ou mesmo por parte dos judeus. E insiste que se há litígio, que se busquem instituições legítimas e adequadas para administrar isso: "audiências e procônsules", ou seja, instituições legítimas. Ele busca restabelecer a ordem e dissuadir a população de se reunir em assembleias espontâneas, chegando a mencionar o recurso de uma "assembleia legal" (v.39). O ponto central de seu argumento se encontra na afirmação que faz a seguir: "De fato, nós estamos correndo o risco de sermos acusados de sedição por causa de nossa reunião de hoje, pois não existe nenhum motivo que possamos apresentar para justificar essa arruaça” (v.40). Com isso, a multidão se dispersou.

Entendemos que a narrativa muito habilmente resolve o problema por meio da intervenção de um personagem oculto, cuja presença é anunciada por meio dos riscos que traz à assembleia. Uma multidão reunida sem convocação oficial, gritando palavras de ordem por horas, podia ser interpretada pelo poder romano como sedição, e dessa forma ser reprimida violentamente. Temos que nos lembrar 
que o próprio culto a Ártemis Efésia era associado ao culto imperial ${ }^{1}$ e ao culto de Roma, de forma que nas procissões da estátua da deusa pela cidade nas festas, as imagens do imperador a acompanhavam. Havia, dessa forma, uma articulação imagética e ideológica clara, porém artificial, entre a religiosidade efesina, em seus mais diferentes níveis, com a ordem pública sob os auspícios do poder romano. Atos dos Apóstolos tendem a avaliar Roma e seus governantes com complacência, atribuindo os conflitos que enfrentam os missionários cristãos a agentes do andar de baixo (os judeus, populacho, grupos internos ou próximos concorrentes). Nessa palavra sobre o risco de "sedição" do secretário e na forma rápida como foi entendida, da mesma forma que na dissolução da assembleia, a presença invisível, mas convincente, de Roma se fez sentir.

\subsection{Atos Apostólicos Apócrifos e a inserção de elementos folclóricos gregos nas narrativas da missão paulina}

Os Atos dos Apóstolos nos permitem um acesso privilegiado a memórias do pluralismo religioso na cidade de Éfeso no primeiro século. O fato de essas memórias serem ficcionais, ou seja, de não podermos atribuir acuidade histórica aos relatos, as torna ainda mais preciosas ao historiador da religião, uma vez que os relatos são remodelados com maior participação das sensibilidades e recursos imaginativos dos narradores. Temos em um relato memórias de acontecimentos e

\footnotetext{
${ }^{1}$ O culto imperial, baseado na "ideologia imperial de poder", tornou-se central para esta unidade desde a época do governo de Augustus (29 a. C.-14 d. C.). Como uma das manifestações da teologia imperial que fundamentava ideológica e religiosamente o Estado romano, o culto imperial não era um fenômeno homogêneo, mas uma síntese carregada de tensão entre a ideologia do culto helenístico ao soberano e as concepções romanas das personalidades extraordinárias favorecida pelos deuses. Ele constituía um laço de unidade do império e símbolo da fidelidade ao imperador e ao Estado da parte de todas as pessoas, envolvia um conjunto de ritos religiosos e sua função principal era a legitimação política da honra do imperador e da sua família. Nesse sentido, ao delimitar o que é "culto imperial" devemos ter cuidado para não encobrirmos as distinções que os antigos faziam da relação entre religião e política. Não havia um termo grego ou latino no período anterior ao cristianismo para religião ou política no sentido em que utilizamos esta palavra. Religio significava reverência, consciência e diligência para com os superiores, não exclusivamente os deuses. A palavra era também usada coletivamente, como designação dos ritos e cerimônias do culto divino e de tudo o que está ligado a ele (res divinae oposta a res humanae). A religio pré-cristã não estava preocupada com virtudes pessoais e interiores, como crença, mas com comportamento e atitude exterior, ou seja, com a observância e não com a fé, com a ação e não com o sentimento. Isso, naturalmente, não quer dizer que os pagãos não experimentavam emoções durante os seus cultos, mas que este aspecto não era central ao conceito e significado de religio. O significado da palavra religião no sentido moderno, como um sistema que envolve ação, rituais e filosofia, teologia, dogmas, cosmologia e mitologia foi desenvolvido especificamente no âmbito da religio Christiana. GRADEL, (2002).
} 
categorias culturais em colaboração. Esse acesso, por mais precioso que seja, não é, no entanto, capaz de oferecer um quadro completo das religiões e nem mesmo do cristianismo no período. Por mais amplo que seja, ele é um fragmento e é dotado de uma perspectiva. É fragmento porque há aspectos de cultos efesinos, e talvez até cristãos, não mencionados. Escrever um relato é escolher e combinar, a partir de certo olhar. Não temos referências a cultos estrangeiros, além dos judaicos, nem qualquer menção a Cibele e a cultos especificamente asiáticos, além da devoção de Ártemis. A perspectiva do relato também apresenta certas marcas específicas. Já observamos acima o interesse da narrativa em mostrar que, a despeito de ter evocado rejeição, o movimento cristão vinculado ao nome de Paulo era perfeitamente ordeiro e ajustado ao poder político. A tensão criada entre a pregação de Paulo e a multidão era um mal-entendido de ourives avaros e o nome de Roma sequer é mencionado claramente na narrativa, figurando como uma ameaça à cidade, por conta da imprudência da multidão que reagia às provocações dos ourives. Em outros casos, como com a comunidade judaica, as tensões foram mais explicitadas.

Os Atos Apócrifos de João (PIÑERO; DEL CERRO, 2012, p. 304-481), redigidos algumas décadas depois dos Atos dos Apóstolos, nos dão um quadro consideravelmente distinto das relações entre o apóstolo João, como representante da comunidade cristã de Éfeso, e o Artemísion. Diz a narrativa que no dia do aniversário do templo, enquanto a multidão se dirigia para a festa vestida de branco, João também para lá se dirigia vestido de negro (cap. 39). A população imediatamente entendeu a provocação e tentou matar o apóstolo, que, por sua vez, os desafiou, ao estilo do profeta Elias contra os sacerdotes de Baal, dizendo que a deusa poderia matá-lo, caso contrário ele os destruiria. O povo ficou atemorizado, enquanto João destruiu o altar e parte do templo, chegando a matar o sacerdote da deusa. Essa cena radical criou muitos problemas para o intérprete acadêmico do texto, uma vez que o templo não havia sido destruído até o final do terceiro século, vítima de terremotos e de invasões dos godos. Por isso, há interpretes que 
atribuem o texto a autores anônimos de fora da Ásia Menor, afinal, como qualquer cristão de Éfeso poderia atribuir a João, no primeiro século, qualquer ação dessa natureza? Nesse período a grandeza do templo é inquestionável. Por esse mesmo motivo, nós somos da opinião de que ninguém, de Éfeso ou de qualquer outra região do mundo mediterrâneo, poderia ter escrito uma narrativa dessa por pura ignorância, sem que quisesse escrever exatamente o que escreveu. Parece-nos ser mais adequado ao estilo imaginativo e ficcional de nossos textos que a narrativa tivesse pretendido provocar seus leitores por meio desse mundo do "como se" da literatura religiosa cristã-primitiva. Esse relato representa, em nossa opinião, um testemunho precioso do sentimento de incompatibilidade entre os cristãos de Éfeso com aquele templo que supostamente representaria sua identidade cívica. Essa narrativa da destruição do Artemísion não é menos expressão de desconforto e oposição religiosa e política do que a profecia de Jesus sobre a destruição do Templo de Jerusalém, mesmo quando ele ainda se encontrava no seu auge.

Há mais uma testemunha antiga da pluralidade do cristianismo em Éfeso que queremos mencionar ao final deste ensaio: trata-se da cena efesina dos Atos Apócrifos de Paulo, tal como preservada no papiro de Hamburg (PIÑERO; DEL CERRO, 2005, p. 787-801). Esse texto, escrito também algumas décadas após os Atos dos Apóstolos, também preserva memórias da ação de Paulo em várias cidades no leste do mundo mediterrâneo, dando destaque à cidade de Éfeso. Ao contrário dos Atos dos Apóstolos, no qual o apóstolo é dissuadido pelos seus companheiros de entrar no teatro durante a reunião da multidão enfurecida, nessa narrativa Paulo é o protagonista de uma cena fantástica e aventureira em pleno teatro. Segundo o papiro Hamburg, Paulo teria convertido à fé cristã Artemila, mulher de Jerônimo, o procônsul. Ocorre que, segundo esse texto, o ideal de relação entre homem e mulher, mesmo casados, é o celibato, o que, por motivos óbvios, criou desconforto e irritação ao poderoso marido Jerônimo. Artemila consegue visitar a Paulo na cadeia, na véspera de sua execução. Ambos, milagrosamente, saem do cárcere e se dirigem à beira do mar, onde Paulo batiza Artemila e a salva de um afogamento. Após essas cenas, ele retorna ao cárcere para 
enfrentar a sua prova. No dia seguinte, Paulo seria entregue às feras. No momento de sua execução, é lançado na arena um leão de estatura descomunal. No entanto, a fera se curva diante de Paulo e o saúda como irmão. Trata-se de um leão que ele encontrara antes, nas montanhas, e que lhe pedira o batismo. Diante da inusitada cena, Paulo e o leão são soltos.

Essa cena, voltada ao entretenimento e à edificação, mostra um alinhamento do cristianismo primitivo com a cultura popular e com o folclore, pois nos oferece uma adaptação cristã da famosa e popular estória de Androcles e o Leão, transmitida por Aulus Gellius, em suas Noites Áticas. Trata-se da estória na qual um escravo fugitivo encontrou numa caverna um leão com um espinho em sua pata, retirou-lhe o espinho e conviveu com ele por anos na mesma caverna. Tendo-se passado muito tempo, o escravo fugitivo é aprisionado e levado a Roma, onde é condenado à morte pelas feras. No dia especificado para sua execução, ele adentra ao anfiteatro, quando é solto um enorme e feroz leão, que imediatamente o reconhece como seu velho amigo. A multidão e o imperador ficam maravilhados com a cena, o que resulta na soltura de ambos.

O uso deste motivo inspirado no folclore nos Atos de Paulo é surpreendente e mostra algumas tendências do cristianismo do segundo século. A primeira se refere a um incremento na imaginação narrativa. Esse relato de Paulo e o Leão parece ser um complemento criativo à referência que Paulo fez em 1Cor 15, quando diz que enfrentou a feras em Éfeso. Talvez ele até se referisse a incidentes semelhantes aos relatados em Atos 19, mas a imaginação de gerações que se seguiram não resistiu à tentação de dar um corpo narrativo àquela referência metafórica. A segunda tendência é a de fazer as tradições e memórias sobre as origens cristãs dialogarem com o folclore, com estórias divertidas e bemhumoradas, como a de Androcles e o Leão. Talvez o adjetivo “divertido" caiba melhor em nossa conta, de intérpretes contemporâneos, podendo a narrativa ter desempenhado algum papel edificante para essas comunidades que, de uma forma 
ou de outra, corriam riscos ao serem instadas ao testemunho público. Nesse relato, de fato, nos defrontamos com um modelo muito popular de cristianismo em Éfeso.

\section{Considerações finais}

Este ensaio buscou analisar a pluralidade do cristianismo em Éfeso, na Ásia Menor, durante o primeiro e o segundo séculos, por meio de suas memórias narrativas da atuação de Paulo de Tarso, tal como preservadas em Atos dos Apóstolos 18 e 19 e nos Atos Apócrifos de Paulo. Trata-se de um corte específico, mas que já permite vislumbrar uma comunidade cristã multifacetada e dinâmica.

Encontramos o cristianismo paulino em tensão com vários modelos e estratos religiosos de Éfeso. O primeiro é representado pela sinagoga judaica, da qual essa comunidade procede e da qual herda modelos de ensino, de ação social, além dos já mencionados dinamismo e versatilidade cultural. O segundo estrato é a religiosidade cívica do templo de Ártemis, com a qual o movimento cristão entra em rota de colisão, ainda que veladamente. O terceiro é o de exorcistas ambulantes judeus que tentar fazer uso mágico do nome de Jesus. Por fim e em quarto lugar, encontramos um grupo de cristãos que são caracterizados "apenas" como seguidores de João Batista, um grupo muito próximo, portanto, do cristianismo paulino, apesar dessa particularidade.

Em relação aos grupos e estratos religiosos acima listados, o grupo missionário paulino se porta de diferentes formas: pretende ser um instrutor de judeus da sinagoga e dos cristãos considerados "incompletos", ensinando a correta leitura da Escritura ou o acesso aos dons proféticos por meio dos rituais apropriados. Em relação ao culto de Ártemis, o texto mantém uma relação ambígua, afinal, tudo não passava de manobra de ourives que tinham claros interesses financeiros na veneração da deusa. Mais ambígua ainda é a postura do texto em relação a Roma e ao culto imperial, uma vez que eles são apenas aludidos no risco de sedição. Por fim, o texto tem seu tom de oposição mais acentuado na 
crítica aos exorcistas judeus ambulantes, por meio de uma narrativa que os expõe ao ridículo. Esse grupo, no entanto, é o que mais apresenta traços de religiosidade popular e, curiosamente, o que mais compartilha da configuração itinerante, taumatúrgica e mágica do movimento paulino. Essa crítica mais acentuada aos exorcistas se deve, provavelmente, ao fato de serem concorrentes diretos do movimento cristão, tal como representado pela narrativa de Atos dos Apóstolos.

Nos Atos Apócrifos de Paulo, pudemos perceber como esse movimento cristão dialoga intensamente com formas de narrativas gregas (como a novela de aventura) e com elementos do folclore. A inserção desses elementos deve ter tornado o cristianismo em Éfeso ainda mais atraente para os estratos populares.

\section{REFERÊNCIAS}

BETZ, Hans Dieter. The Greek Magical Papyri in Translation. Including the Demotic Spells. 2. ed., vol. One: Texts. Chicago: The University of Chicago Press, 1992.

COHEN, Shaye. The Beginnings of Jewishness. Boundaries, Varieties, Uncertainties. Berkeley: University of California Press, 2000.

COMBY, Jean. ; LEMONON, Jean-Pierre. Roma em face a Jerusalém. Visão de autores gregos e latinos. Documentos do Mundo da Bíblia 5. São Paulo: Paulinas, 1987.

GRADEL, Ittai. Emperor Worship and Roman Religion. Oxford: Clarendon Press, 2002.

FRIESEN, Steven. The Cult of the Roman Emperors in Ephesus: Temple Wardens, Citu Titles, and Interpretation of the Revelation of John. In: KOSTER, Helmut (ed.). Ephesos. Metropolis of Asia. An Interdisciplinary Approach to its Archaeology, Religion, and Culture. Valley Forge: Trinity Press International, 1995, p. 229-250.

KOESTER, Helmut. (ed.). Ephesos. Metropolis of Asia. An Interdisciplinary Approach to its Archaeology, Religion, and Culture. Valley Forge: Trinity Press International, 1995.

NOGUEIRA, Paulo A S. Experiência religiosa e crítica social no cristianismo primitivo. São Paulo: Paulinas, 2003. 
OSTER, Richard. E. Ephesus as a Religious Center under the Principate. I. Paganism before Constantine. In: HAASE, Wolfgang (hg.). Aufstieg und Niedergang der Römischen Welt (ANRW). Teil II: Principat, Band 18, 3. Teilband. Berlin: Walter de Gruyter, 1990, p. 1661-1728.

PERVO, Richard. I. Profit with Delight. The Literary Genre of the Acts of the Apostles. Philadelphia: Fortress Press, 1987.

PIÑERO, Antonio; DEL CERRO, Gonzalo. Hechos Apócrifos de los Apóstoles. v. 2: Hechos de Pablo y Tomás. Madrid: Biblioteca de Autores Cristianos (BAC), 2005.

PIÑERO, Antonio ;DEL CERRO, Gonzalo. Hechos Apócrifos de los Apóstoles. v. 1: Hechos de André, Juan y Pedro. Madrid: Biblioteca de Autores Cristianos (BAC), 2012.

ROGERS, Guy MacLean. The Sacred Identity of Ephesus: Foundation Myths of a Roman City. London/New York: Routledge, 2014.

THOMAS, Christine. At Home in the City of Artemis: Religion in Ephesus in the Literary Imagination of the Roman Period. In: KOSTER, Helmut (ed.). Ephesos. Metropolis of Asia. An Interdisciplinary Approach to its Archaeology, Religion, and Culture. Valley Forge: Trinity Press International, 1995, p. 81-118.

TREBILCO, Paul. The Early Christians in Ephesus from Paul to Ignatius. Grand Rapids: Eerdmans, 2008.

WEISER, Alfons. Die Apostelgeschichte Kapitel 13-28. Ökumenischer Taschenbuchkommentar zum Neuen Testament 5/2. Gütersloh: Gütersloher Verlagshaus, 1985 . 